\title{
The History of the Arab Nation and the Arabic Language
}

\author{
Hu Huafeng ${ }^{1, ~}$, Fan Zhihao ${ }^{1}$, Gao Xuezhen ${ }^{2}$ \\ ${ }^{1}$ School of Energy and Mechanical Engineering,-Shanghai University of Electric Power, Shanghai, China \\ ${ }^{2}$ School of Stomatology, Zhejiang University of Traditional Chinese Medicine, Hangzhou, China
}

Email address:

13605725298@163.com (Hu Huafeng),1351757423@qq.com (Fan Zhihao), 1317287731@qq.com (Gao Xuezhen)

${ }^{*}$ Corresponding author

\section{To cite this article:}

Hu Huafeng, Fan Zhihao, Gao Xuezhen. The History of the Arab Nation and the Arabic Language. Arabic Language, Literature \& Culture. Vol. 4, No. 3, 2019, pp. 48-53. doi: 10.11648/j.allc.20190403.11

Received: September 16, 2019; Accepted: September 28, 2019; Published: October 14, 2019

\begin{abstract}
Kingdom of Saudi Arabia (English: Kingdom of Saudi Arabia, Arabic: مملكـة عربيسة سـودية), known as Saudi Arabia (Saudi Arabia, Taiwan translated as Saudi-Arabia), referred to Saudi Arabia. Saudi Arabia is located in southwest Asia, the Arabian Peninsula, east near the Persian Gulf, west of the Red Sea, which borders with Jordan, Iraq, Kuwait, the United Arab Emirates, Oman, Yemen, Bahrain, Qatar, and other countries. Saudi Arabia is a veritable "oil kingdom," oil reserves and production rank first in the world, making it one of the world's wealthiest countries. Saudi Arabia is the world's largest producer of desalinated water, and desalination accounts for about $21 \%$ of the world total. Saudi Arabia to implement liberal economic policies. Mecca is the birthplace of the founder of Islam Mohammed, a Muslim pilgrimage to the Holy Land. The kingdom of Saudi Arabia as the only Arab state in the two pillars of the United States in the Middle East and as the master of the Islamic alliance has to be of concern to us. Especially in the current era, the kingdom of Saudi Arabia is faced with the increasingly prominent double-edged sword effects such as religion, oil wealth, emerging middle class and excellent power influence, and its political modernization trend has to be reflected.
\end{abstract}

Keywords: Arabic, National Culture, Future Path, Political System

\section{Introduction}

Early Arab states appeared in the south of the Arabian peninsula in the 8th century BC. In the 7th century, Muhammad founded Islam and unified the Arabian peninsula. Later, the Arab rulers gradually built up an Arab empire spanning Asia, Africa, and Europe. The Arab empire disintegrated in the early 11 th century and has since been ruled by the Seljuk Turks (11th to 12th centuries), the Mongols (13th to 14 th centuries), and the Ottoman Turks (14th to early 20th centuries).

From the 17th century, the Arab world was gradually reduced to colonies and semi-colonies of western capitalist powers. After world war I, the Ottoman Empire collapsed, and a handful of countries, including Egypt, Saudi Arabia, Iraq, and Oman, gained formal independence. After world war ii, the national liberation movement of Arab countries arose, and Arab countries achieved national independence one after another.

Saudi Arabia is the world's largest barley importer, the annual import about 600 million tons. Fruits self-sufficiency rate of $60 \%$. Livestock mainly sheep, goats, camels and so on. The main agricultural products are wheat, corn, dates, citrus, grapes, pomegranate. Saudi Arabia's grain self-sufficiency rate is relatively low, only $20 \%$ and more, rely heavily on imports to meet demand. [3]

Saudi Arabia's financial system and improve the well-developed, Saudi Arabia's tourism industry is relatively developed. The Saudi government encouraged the development of private economy in order to reduce the country's economic dependence on oil exports while providing more employment opportunities for the rapidly growing population. Saudi Arabia also uses a lot of foreign workers. Focus on economic development, industrial, petroleum and petrochemical industry is the lifeblood of the national economy, is the primary source of income. [4]

The Arab nation refers to residents from the Arabian Peninsula desert, the semi-desert region of southern Yemen, whether under Jewish "Bible" and Islamic "Koran" in the records, and they think that Jewish blood, language 
classification also belong Semitic languages. The original are some of the family as the basis of tribes scattered in the Arabian Peninsula.

From the start of the second half of the 6th century, due to the chaotic years of war between Egypt and the Byzantine and Persian, so that the original Persian Gulf - Red Sea - Nile trade routes impassable, business people change to go safer by Arab land peninsula. Located in the middle of trade routes, east to the Persian Gulf, the Red Sea, west, north to Syria, Yemen Nantong transport hub, industrial city of Mecca thus become prosperous together.

\section{Development Process}

\subsection{Origin of Nationality}

The national origin of the Arabs can be traced back to the ancient Gillemite tribe, and they think that they are the descendants of Ishmael. In that early part of the first century, after the rise of Islam, the tribes of the Arab tribes, under the banner of the Islamic sharia, began to expand and expand rapidly, and, in the middle of the eighth century, the east and the Indus were set up.

\subsection{National Development}

Arabs had two different concepts before and after the rise of Islam. Before Islam and Arabic were widely spread, Arabs were nomadic (Semitic) residents of the Arabic Peninsula. After the Arab Empire, residents of the Middle East and North Africa accepted Islam and Arabic and experienced mixed races. Form a linguistic and cultural group linked to Islam and Arabic.

In modern times, Arabs include Arabic-speaking residents from Morocco in western Africa to swamps in southwest Iran, covering all parts of the Maghreb (Maghreb) in North Africa, the Arabic Peninsula, and the Middle East.

The early Arabs of the Arabic Peninsula before the birth of Islam, mainly nomads grazing sheep, goats, and camels in deserts. To date, the distinction between desert nomadic tribes and citizens and farmers is still widespread in the Arab world. At that time, the Arabs believed in primitive religion. The Arabs in the south mainly worshipped the sun, moon, and stars, while the Arabs in the north worshipped springs, rocks, and plants as gods. At that time. Arabs are still in the stage of clan society. When Islam arose in the 6th century $\mathrm{AD}$, the Byzantine Empire and the Persian Empire frequently fought, which almost interrupted the commercial road through the Red Sea, thus stimulating the trade activities of the Mecca Gules, considerably shaking the local clan social system, the emergence of private ownership, and Mecca began to prosper.

\subsection{National Rise}

\subsubsection{Mohammed Established Islam}

Mohamed, the Prophet of Islam, came from the aristocratic Hamshi clan, but the family has fallen. When Mohamed was still in her mother's belly, his father went out to do business and died of illness. Mohamed grew up in the desert and returned to Mecca at the age of five. His mother died of illness at the age of six and has since been raised by his grandfather and uncle. When Mohamed was 25 years old, he was employed by the rich widow Hetticher and went to Syria to do business. Soon after, Mohamed married in Herticher and went home ever after.

Mohamed, however, is not greedy for wealth and often goes to caves on the outskirts of Mecca during the ban month (September Islamist calendar) to meditate, meditate and seek true faith. It is said that one night in 610, Allah's revelations began to come. Muslims later called the night "night of authorization" (the Quran called it a "noble night"). From that day on, Islam was born, and Mohamed began his career in spreading Islam.

After the establishment of Islam, Mohamed preached in secret, very few people, and most of them relatives and friends. In about 612 , Mohamed preached publicly but was opposed by the Gules people, and Islam was in danger of dying. In 621, Mohamed and the Yeslib entered into an oath on the outskirts of Mecca: Mohamed was in charge of mediating the Yesrib tribe, which was converted to Islam by. 6 and 12 people, respectively. In 621, Mohamed and the Yesrib made a vow on the outskirts of Mecca: Mohamed was in charge of mediating the Yesrib tribe. Then Muslims in Mecca began to move to Yesrib, known as emigrants, who were core members of early Muslims.

Arabs and Islam had a significant influence in Asia and North Africa, and at the height of the Arab Empire, groups of Arabs went out to do business or preach, spreading Islam around the world. With the spread of Islam and the great idea that "all Muslims are brothers" stipulated in the Koran, the foundation of the Arab clan society linked by consanguineous relations has been greatly shaken, and different Muslim ethnic groups have been able to unite with each other and develop together. Hundreds of millions of Muslims who advocate Islamic tolerance, freedom, and equality sincerely support and follow Islam, even with blood and life, to safeguard the dignity of Islam. Allah The contribution of Bo people is essential, mainly in literature, mathematics, history, and other fields, as well as cultural exchange, development and inheritance.

Arab scientific contributions are mainly reflected in the translation of Greek, Latin, and Persian books. In the golden age of Islam, a large number of literature and scientific books were translated into Arabic, which significantly promoted the development of culture in the Arab world. At the same time, Arab people in business contributed to the promotion of cultural exchanges.

\subsubsection{The Establishment of a Caliphate and the Beginning of Conquest}

When the prophet Mohamed was alive, he neither left his son nor specified who would be his heir. As a result, after his death, the problem of successors became the primary problem for Muslims. Around this problem, there was a 
fierce competition between the auxiliary school, the emigration school, the legalism school, and the $\mathrm{Wu}$ Maine school.

When Mohamed was alive, tribes sent delegations to Medina to show obedience to the prophets when Mecca fell behind. However, after his death, many tribes separated from Medina's rule and returned to freedom, and some even engaged in chaos and threatened Medina. The first thing that happened was the Essid and Gatterian tribes, not far from Medina. The more serious is the Hanif rebellion in the Yemaimai area headed by the pseudo-Prophet Muselemay and the Tamim rebellion led by the Prophet Saijaha. In addition, there have been varying degrees of rebellion in Bahrain, Oman, Hadarama, and Yemen.

Against insurgency everywhere. Caliphate Abb and Burker took stringent measures, resolutely and decisively put them down in military action, quickly stabilized the situation, safeguarded the national unity on the peninsula, not only enabled the rebels to accept Islam again, but also made those in remote areas who had not yet been affected by the new religion believe in Islam, thus Islamizing the whole Arab Peninsula and laying the foundation for the beginning of the conquest movement. In the rebel movement, Khalid Ben Walid was resourceful, brave, and good at war, repeatedly building extraordinary achievements, and was named "the sword of Allah."

At the same time, after Khalid led reinforcements to arrive, the western battlefield significantly strengthened its strength and won one victory after another, and the Byzantine army was defeated. The Arab army, several cities, forced Damascus to surrender on September 635. On August 20, 636, the two armies fought in Yermuk (Yarmouk), the Byzantine army was crippled and defeated, and the Lord Theodoras died. The Arab army chased after him and went straight to the Taurus Mountains on the Syrian border. At the same time, the march in Palestine was very smooth, attacking many cities in succession. In 638, the famous religious holy city of Jerusalem surrendered. At this point, Greater Syria, including Damascus, Homs, Jordan, and Palestine, is entirely in the hands of Arabs.

The caliphate government attached great importance to the spread of Islam, hired Islamic scholars to participate in the government, and continuously sent teachers to various places, and later sent Islamic judges to the provinces. This has played an essential role in accelerating Islamization everywhere.

\subsection{Modern Development}

In the 20th century, the traditional values of the Arab world were changed under the pressure of urbanization, industrialization, non-tribalization, and western influence. Nearly half of Muslim Arabs live in cities and towns, and family and tribal ties are gradually broken, with women and men getting more education and jobs, and the emerging middle class, made up of technicians, professionals, and officials, has gained power.

The majority of the Arabs continue to live in small and isolated rural areas, where traditional values and traditional industries still prevail, including women's inferiority and family segregation (deep-rooted). The majority of urban Arabs tend to be divided by occupation or nationality without tribal distinctions, while farmers still respect the flow of livestock (nomadic) and claim that they have a blood-related relationship with the past and large tribes in the desert. The change of nationalism and lifestyle caused by the development of the oil industry has made a fundamental change in the nomadic life. The traditional Arab culture of the typical life of the nomads accounts for only 10 percent of the modern Arab population. The rest of the tour Many of the herdsmen have given up all nomads, or live in rural areas, raise livestock, hire oil companies, or seek other jobs in cities and towns.

In the course of modernization in Arab countries, there are many remarkable characteristics, such as exogenous modernization road, distinct Islamic characteristics, rapid leaping change, dualistic structural model, multi-channel development model, and continuous religious tradition reform and so on. As a country with a unique history, the Kingdom of Saudi Arabia has a more distinctive political modernization process.

\section{The Development History of the Arabic Language}

\subsection{Summarize}

Belonging to the Semitic language family, mainly spoken in Western Asia and North Africa, is the official language of the following 22 countries: Saudi Arabia, Yemen, United Arab Emirates, Oman, Kuwait, Bahrain, Qatar, Iraq, Syria, Jordan, Lebanon, Palestine, Egypt, Sudan, Libya, Tunisia, Somalia, Djibouti, Mauritania, Comorian, Algeria and Morocco. In addition, some Hui people in China also speak Arabic. More than 210 million people speak Arabic as their mother tongue; at the same time, Arabic is the religious language of Muslims all over the world. Arabic is written and disseminated; Muslims can more or less understand Arabic.

Arabic originated in Semitic, an ancient language. Around the 5th century AD, a unified Arabic literary language was formed based on the Organization of French-speaking countries in the Northern dialect: members. With the spread of Islam and the rise and expansion of the Arab Empire in the 7th century, as well as the introduction of Arabs and Islam to other countries, the language soon became the Indus River in the east, Gibraltar in the west, and North Africa in the south. As far as the Caspian Sea, the common language of all ethnic groups who believe in Islam in this vast area of the Caspian Sea; In the Middle-Century of Europe, it was a medium for the preservation of Greek culture and the communication of Eastern and Western cultures.

On the southern coast of the Arabic Peninsula, there are several dialects, collectively known as Southern Arabic, 
which are very different from Northern Arabic.

In the nearly 300 years since the creation of Islam in the first half of the 7th century, with the expansion of Arabs outside the peninsula and the invasion of foreign languages, Arabic dialects have gradually formed significant differences from literary languages. Now, Arabic dialects have developed into Syria, Iraq, Meiji and Shijazi, Yemen, Egypt, Tunisia, Algeria, Morocco, with the most influential Egyptian dialects.

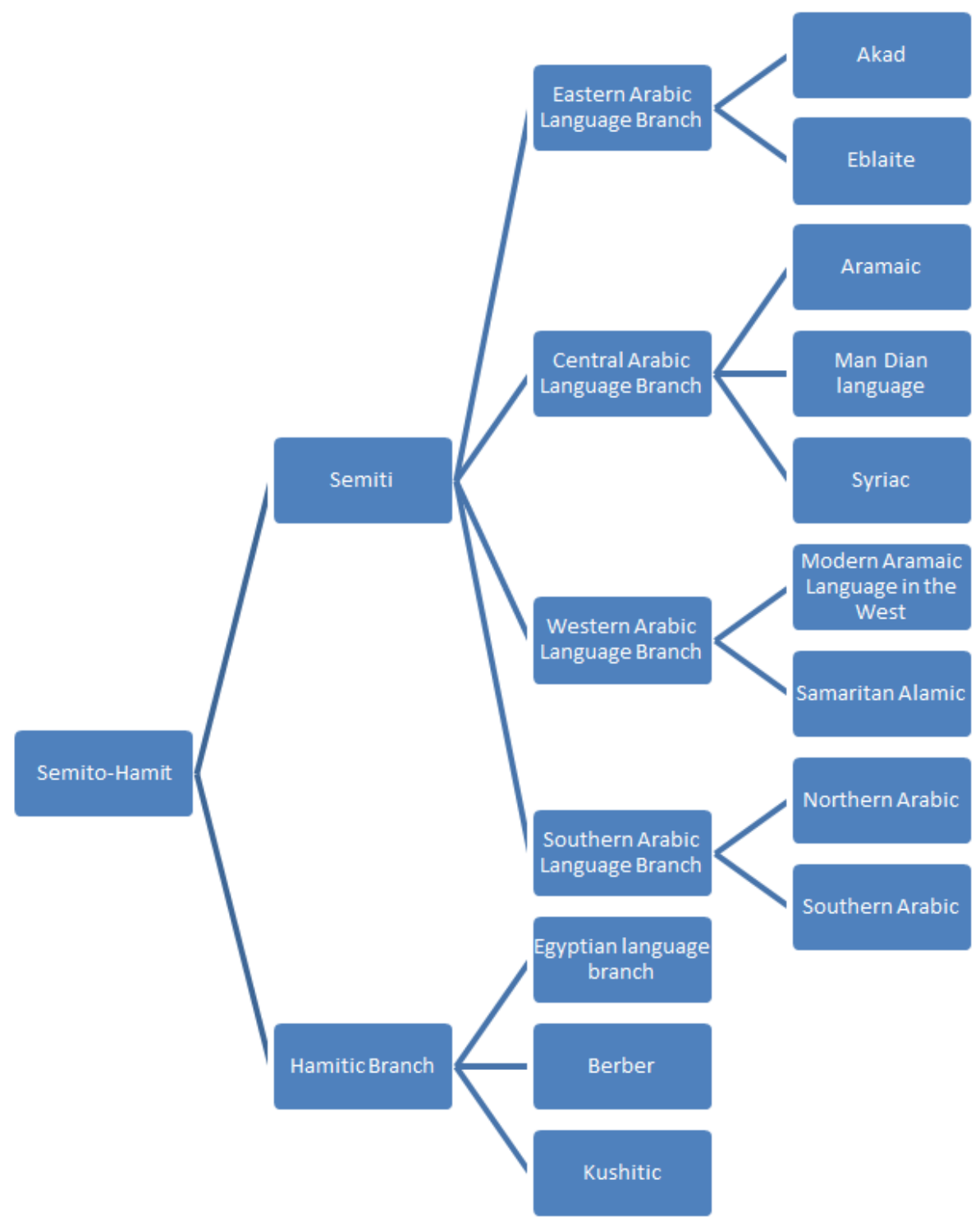

Figure 1. The Development History of the Arabic Language.

\subsection{The History and Contribution of Arabic}

The Arabic language originated from an ancient Semitic language. Around the 5th century $\mathrm{AD}$, a unified Arabic literary language was formed based on northern dialects. With the rise of Islam and the Arab Empire and the introduction of Arabs and Islam to other countries in the 6th century AD, Arabic completely replaced the languages formerly used in Iraq, Syria, Egypt, and North Africa. Many linguists believe that Arabic is the closest language in the Semitic family to the ancestral language of Semite. The language soon became Islamic in large part of the Caspian Sea, from the Indus River in the east, to Gibraltar in the west, to North Africa, and the Caspian Sea. The common language of the nation; in the Middle-Century of Europe, it was a medium for the preservation of Greek culture and the communication of Eastern and Western cultures. After the decline of the Arab Empire, Arabic-speaking areas shrank significantly, but it had a huge cultural impact on many parts of Asia, Africa, and Europe. Such as Persian, Turkish, Urdu, Indonesian, Kiswahili, Hausa, and other 36 languages have absorbed a large number of Arabic words and spelled in Arabic letters, including Persian, Urdu and Chinese Uighur. Arabic has 8 vowels and 28 consonants, characterized by multiple top sounds and throat sounds. It is known as German because it has the top sound of dad (Dade) in all languages of the world.

Arabic is the language of life for the Arab nation and the same voice for nearly 1.5 billion Muslims around the world. During the centuries of the Middle Ages, Arabic was one of the languages used in the academic culture of the whole 
civilized world. Works wrote in Arabic in the 12th century, including philosophy, medicine, history, religion, astronomy, geography, accounted for a large proportion of other languages.

There are still many Arabic words in the languages of Western Europe, which is enough to explain the influence and promotion of Arabic on human civilization.

In the world language, in addition to the Latin alphabet, the Arabic alphabet is the most widely used set of letters, the languages using the Arabic alphabet are: Persian, Kurdish, Pashto, Urdu, some Turkic, Berber, Malay and Uygur, Kazakh, Uzbekistan and so on. The Arabic Peninsula is the birthplace of the Arabic language, and the Arabs take the Arabic language wherever they go. The fall of the Koran makes the Arabic language shine. The Koran is fashionable and beautiful, catchy, sonorous and forceful, and is regarded as an encyclopedia of Islam. Become a later grammar; rhetoric created a grammar. The fundamental basis of rhetoric is also the best model for poets to write poems. So far, the classical model texts used in Arab colleges and universities come from the Koran.

The emergence of human language means the beginning of brilliant and colorful human culture. Generally speaking, culture and language are symbiotic, language is the key to the emergence and development of culture, and the development of culture, in turn, promotes the enrichment and fineness of language. The relationship between language and religion and culture is inseparable. On this basis, after 1500 years of gradual change, and grammatists, scholars continue to improve based on the Koran. Among the different languages in the world, Arabic has become an ancient and young three-dimensional language.

\subsection{The Historical Connotation of the Arabic Language}

The ancient Arab nomadic tribes are good at expressing their feelings with poetry, and the famous suspended poetry is the most persuasive evidence. From a certain point of view, the suspense poem shows the original Arab culture created by nomadic tribes. From the middle of the 7 th century, the Gulai dialect has become the core and foundation of Arabic language. The Koran not only protects the existence of Arabic but also promotes the development of Arabic. If Muslims want to understand Islamic teachings and Shariah, they must first learn Arabic. Only by getting through with Arabic can we better understand Islam. In other words, Arabic is the basis and prerequisite for a correct understanding of Islamic knowledge. Many language disciplines based on the Koran make the connotation of Arabic more abundant. In order to understand the Koran correctly, it is convenient for people to understand the Koran correctly. We learn and master Arabic, and scholars do their best to study and work out complete rules of Arabic grammar. The purpose of studying Arabic grammar is to understand the Koran better, and the study of the Koran promotes effective changes in the connotation and extension of Ala's language. The close complementarity between the two attests to the concrete efforts made by the Arab nation to preserve, carry forward Arabic, and make it continue so far. Gulai dialect symbolizes the life mode of the ancient Arab nomadic people, which is monotonous and limited. "hanging Poems" insinuates the information and cultural exchange state of the tribes, which is productive and straightforward. However, neither has left the Arabian Peninsula, although there have been some changes before and after time, and the limitations of space are significant. When the Koran was reduced, Arabic broke through the boundaries of time and space and made significant progress.

\subsection{Arabic Developed in Multidimensional Spatio-temporal}

Arabic originated in the vast desert, accompanied by nomads active in the two river basins in the Sham area, the Nile valley, along the Mediterranean coast. In the exchanges with ancient Syria, Alami, Coptic, Berber and other ethnic groups, Arabic gradually replaced the languages used by the local indigenous people, so that the local culture attached to the pronounced Arabic color. After centuries of baptism, Arabic, dominated by the Gulai dialect, became the medium of expression of the aspirations of the peoples as mentioned above. Whether in Damascus, Baghdad, or Nishapur, Faustadt Kerouan, Kordova, even Bukhara, Delhi, and so on, Ala. Bo is the local common language. Even so, it is not difficult to find Arabic foreign words, such as Persian and Aramaic, to make Arabic plump and perfect.

\section{Conclusion}

Arab language, belonging to the Semitic language family, using the Arabic alphabet, mainly in the Middle East and North Africa, is now the official language of 22 Arab countries and 4 international organizations. More than 200 million people speak Arabic as their mother tongue. Arabic, the religious language of Islam, has reached more than 400 million users worldwide. Arabic dialects are many and different, while standard Arabic is based on the classic Koran.

Arabic is the mother tongue of the Arab nation and the language used by nearly 1.5 billion Muslims around the world to carry out their religious lessons. The same voice of "Allah Akbar" can be heard in Arabic every day in any corner of the world. During the centuries of the Middle Ages, Arabic was one of the languages used in the academic culture of the entire civilized world.

\section{References}

[1] Watenpaugh K D. Cleansing the cosmopolitan city: historicism, journalism and the Arab nation in the post-Ottoman eastern Mediterranean [J]. Social History, 2005, 30 (1): 1-24.

[2] Zaman M Q. Arabic, the Arab Middle East, and the Definition of Muslim Identity in Twentieth Century India [J]. Journal of the Royal Asiatic Society, 1998, 8 (1): 59-81.

[3] Elsadda H. Gender, Nation, and the Arabic Novel: Egypt, 1892-2008 [M]// Gender, nation, and the Arabic novel: Egypt, 1892-2008. 2012 
[4] Chejne A G. The Arabic Language; Its Role in History. [J]. Die Welt Des Islams, 1969, 5 (13): 240.

[5] Suleiman Y. The Arabic Language and National Identity: A Study in Ideology. [J]. Arabic, 2003, 27 (2): 324-325.

[6] Harris R S. Hebraizing the Arab-Israeli: Language and Identity in Ayman Sikseck's To Jaffa and Sayed Kashua's Second Person Singular [J]. Journal of Jewish Identities, 2014, 7 (2): 35-58.

[7] Sharkey H J. Language and Conflict: The Political History of Arabisation in Sudan and Algeria [J]. Studies in Ethnicity \& Nationalism, 2012, 12 (3): 427-449.

[8] Nashef H A M. A dialogue beyond the nation-state: Darwish's Mural and Shehadeh's A Rift in Time: Travels with my Ottoman Uncle [J]. Interventions International Journal of Postcolonial Studies, 2018, 20 (2): 1-15.

[9] Benigni E. Translating Machiavelli in EgyptEgypt: The Prince and the Shaping of a New Political Vocabulary in the Nineteenth-Century Arab Mediterranean [M]// Machiavelli, Islam and the East. 2018.

[10] Hakim M, Jabour A, Anton M, et al. Screening Arab Israeli Pregnant Women for Group B Streptococcus by the AmpliVue GBS Assay: Are the Rates Higher than the National Average? [J]. Israel Medical Association Journal Imaj, 2018, 5 (20): 291.

[11] Ponnuchamy G. History of English-as-A-Second-Language Teaching in the Middle East and the Current Scenario in Bahrain [J]. Social Science Electronic Publishing, 2018.

[12] Khaled S M, Kimmel L, Trung K L. Assessing the factor structure and measurement invariance of the eating attitude test (EAT-26) across language and BMI in young Arab women [J]. Journal of Eating Disorders, 2018, 6 (1): 14-19.

[13] Almusawi M. Postcolonial Theory in the Arab World: Belated Engagements and Limits [J]. Interventions, 2018: 1-18. 